\title{
Demokrasi Indonesia
}

\author{
Wahyu Amir Mustofa \\ IIK STRADA Indonesia \\ Wahyuamirmustofa75@gmail.com
}

\begin{abstract}
Abstrak
Demokrasi merupakan nilai universal sebagai kehendak rakyat yang di ekspresikan secara bebas,untuk menentukan sistem ekonomi,politik,sosial,dan budaya. Secara sederhana demokrasi di gambarkan sebagai “ Pemerintahan dari rakyat,oleh rakyat ,dan untuk rakyat”. Pada hakekatnya demokrasi di capai untuk kemakmuran.
\end{abstract}

\section{Latar Belakang}

Di indonesia telah banyak menganut sistem pemerintahan pada awalnya. Namun, dari semua sistem pemerintahan, yang bertahan mulai dari era reformasi 1998

sampai saat ini adalah sistem pemerintahan demokrasi. Meskipun masih terdapat beberapa kekurangan dan tantangan disana sini. Sebagian kelompok merasa merdeka dengan diberlakukannya sistem domokrasi di Indonesia. Artinya, kebebasan pers sudah menempati ruang yang sebebas-bebasnya sehingga setiap orang berhak menyampaikan pendapat dan aspirasinya masing-masing.

Demokrasi merupakan salah satu bentuk atau mekanisme sistem pemerintahan suatu negara sebagai upaya mewujudkan kedaulatan rakyat atau negara yang dijalankan oleh pemerintah. Semua warga negara memiliki hak yang setara dalam pengambilan keputusan yang dapat mengubah hidup mereka. Demokrasi mengizinkan

warga negara berpartisipasi baik secara langsung atau melalui perwakilan dalam perumusan, pengembangan, dan pembuatan hukum.

Demokrasi mencakup kondisi social, ekonomi, dan budaya yang memungkinkan adanya praktik kebebasan politik secara bebas dan setara.

Demokrasi Indonesia dipandang perlu dan sesuai dengan pribadi bangsa Indonesia. Selain itu yang melatar belakangi pemakaian sistem demokrasi di Indonesia. Hal itu bisa kita temukan dari banyaknya agama yang masuk dan berkembang di Indonesia, selain itu banyaknya suku, budaya dan bahasa, 
kesemuanya

merupakan karunia Tuhan yang patut kita syukuri.

\section{Rumusan Masalah}

- Apakah yang dimaksud dengan demokrasi?

- Apa sajakah jenis-jenis demokrasi?

- Bagaimana ciri-ciri demokrasi?

- Apa sajakah contoh-contoh demokrasi?

\section{Tinjauan Pustaka}

- Ketuhanan yang berkebudayaan atau Ketuhanan Yang Maha Esa.

Ketuhanan adalah kerangka pancasila mencerminkan komitmen etis bangsa Indonesia untuk menyelenggarakan kehidupan publik politis yang berdasarkan nilai-nilai moralitas dan budi perkerti yang luhur di bawah panduan nilai-nilai Ketuhanan, pancasila bisa memberikan landasan moral dan filosofis bagi sistem demokrasi yang hendak kita kembangkan. Dengan adanya pernyataan tersebut, maka peneliti dapat mengambil kesimpulan bahwa dengan nilai Ketuhanan yang ada dalam pancasila maka dapat menjadi dasar dan landasan dalam mengembangkan demokrasi bangsa Indonesia, yakni demokrasi pancasila.

- Kemanusiaan universal atau kemanusiaan yang adil dan beradab. Sila peri kemanusiaan yang adil dan beradab, apabila digali merupakan visi bangsa Indonesia yang mengandung begitu banyak nilai manusiawi yang bisa dijadikan pegangan dalam mengantisipasi tantangan globalisasi. Dalam sila ini diharapkan bangsa Indonesia dapat berkomitmen untuk menegakkan nilai kemanusiaan, khususnya hak asasi manusia yang merupakan salah satu prinsip demokrasi pancasila.

\section{Pembahasan}

\section{A. Pengertian Demokrasi}

Demokrasi berasal dari bahasa Yunani "Demokratia"yang berarti kekuasaan rakyat. Demokrasi berasal dari kata "Demos" dan "Kratos". Demos yang memiliki arti rakyat dan Kratos yang memiliki arti kekuasaan. Menurut Kamus Besar 


\section{Bahasa}

Indonesia (KBBI) Demokrasi adalah gagasan atau pandangan hidup yang mengutamakan persamaan hak dan kewajiban serta perlakuan yang sama bagi semua warga negara. Berikut ini adalah pengertian demokrasi menurut beberapa ahli :

1. Demokrasi menurut Montesque, kekuasaan negara harus dibagi dan dilaksanakan oleh tiga lembaga atau institusi yang berbeda dan terpisah satu sama lainnya, yaitu pertama, legislatif yang merupakan pemegang kekuasaaan untuk membuat undang-undang, kedua, eksekutif yang memiliki kekuasaan dalam melaksanakan undang-undang, dan ketiga adalah yudikatif, yang memegang kekuasaan untuk mengadili pelaksanaan undang-undang. Dan masing-masing institusi tersebut berdiri secara independen tanpa dipengaruhi oleh institusi lainnya.

2. Demokrasi menurut Abraham Lincoln yaitu pemerintahan dari rakyat, oleh rakyat, dan untuk rakyat.

3. Demokrasi menurut Aristoteles mengemukakan ialah suatu kebebasan atau

prinsip demokrasi ialah kebebasan, karena hanya melalui kebebasanlah setiap

warga negara bisa saling berbagi kekuasaan didalam negaranya. Aristoteles pun mengatakan apabila seseorang hidup tanpa kebebasan dalam memilih cara hidupnya, maka sama saja seperti budak.

4. Demokrasi menurut $\mathrm{H}$. Harris Soche ialah suatu bentuk pemerintahan rakyat, karenanya kekuasaan pemerintahan melekat pada rakyat juga merupakan HAM bagi rakyat untuk mempertahankan, mengatur dan melindungi diri dari setiap paksaan dalam suatu badan yang diserahkan untuk memerintah.

B. Jenis-jenis Demokrasi

Demokrasi memiliki banyak jenisnya. Berikut beberapa jenis dari demokrasi :

1. Demokrasi menurut cara aspirasi rakyat

a. Demokrasi Langsung Merupakan sistem demokrasi yang memberikan kesempatan kepada seluruh warga negaranya dalam permusyawaratan saat menentukan arah kebijakan umum dari negara atau undang-undang.

b. Demokrasi Tidak Langsung Merupakan sistem demokrasi yang dijalankan menggunakan sistem perwakilan. 


\section{Demokrasi Berdasarkan Prinsip Ideologi}

a. Demokrasi Liberal

Merupakan Kebebasan individu yang lebih ditekankan dan mengabaikan kepentingan umum

b. Demokrasi Rakyat

Merupakan demokrasi yang didasarkan pada paham sosialisme dan komunisme dan lebih mengutamakan kepentingan umum atau negara.

c. Demokrasi Pancasila

Merupakan demokrasi yang ada di Indonesia bersumberkan pada nilainilai sosial budaya bangsa serta berazaskan musyawarah mufakat dengan memprioritaskan kepentingan seluruh msyarakat atau warga negara.

Demokrasi pancasila fokus pada kepentingan dan aspirasi serta hati nurani rakyat. Sampai saat ini Indonesia menganut demokrasi pancasila yang bersumber pada falsafah pancasila.

\section{Ciri-Ciri Demokrasi}

Ciri yang menggambarkan suatu pemerintahan didasarkan oleh sistem demokrasi

seperti:

- Pemerintahan didasarkan kehendak dan kepentingan semua rakyat.

- Ciri konstitusional ialah hal yang berhubungan denag kepentingan, kehendak atau kemauan atau kekuasaan rakyat yang dituliskan dalam konstitusi dan undang-undang negara tersebut.

- Ciri perwakilan yakni dalam mengatur negaranya kedaulatan rakyat akan diwakilkan oleh beberapa orang yang sudah dipilih oleh rakyat itu sendiri.

- Ciri pemilihan umum yakni sebuah kegiatan politik yang dilaksanakan untuk memilih pihak dalam pemerintahan.

- Ciri kepartaian yakni partai akan menjadi media atau sarana untuk menjadi bagian dalam melaksanakan sistem demokrasi.

- Ciri kekuasaan ialah adanya pembagian dan pemisah kekuasaan. 
- Ciri tanggung jawab ialah adanya tanggung jawab dari pihal yang sudah

dipilih untuk ikut dalam pelaksaan suatu sistem demokrasi.

D. Contoh Demokrasi

1. Jenis-Jenis Demokrasi

Demokrasi Langsung

Contoh : Ikut mencoblos saat pemilu atau pilkada, dan memilih secara langsung ketua kelas.

Demokrasi Perwakilan

Contoh : Pembuatan undang-undang yang diwakili oleh anggota DPR

2. Demokrasi perwakilan dengan sistem pengawasan langsung dari rakyat dibagi 3 :

- Referendum Wajib

Contoh : Pemungutan suara pemisahan Timor-Timur, dan persetujuan yang diberikan oleh rakyat terhadap pembuatan UUD.

- Referendum Tidak Wajib

Contoh : Peranan partai politik tidak begitu menonjol tetapi kehendak rakyat dapat diketahui secara langsung dalam demokrasi.

- Referendum Konsultatif

Contoh : Rayat sendiri kurang memahami tentang ini maka pada saat materi UU rakyat hanya diminta persetujuan.

3. Demokrasi berdasarkan titik perhatian atau prioritas :

- Demokrasi Formal

Contoh : adanya keberadaan lembaga-lembaga perwakilan rakyat.

- Demokrasi Material

Contoh : Mungkin keberadaan lembaga-lembaga perwakilan rakyat hanya sebagai simbol saja, dan hanya mementingkan kepentingan negara saja dibandingkan rakyat.

- Demokrasi Campuran

Contoh : Rakyat memilih wakil di DPRD kemudian wakil itu dikontrol oleh rakyat dengan sistem referendum.

4. Demokrasi berdasarkan prinsip ideologi :

- Demokrasi Liberal

Contoh : Dalam demokrasi ini adanya sistem multi partai dan Demokrasi 
ini telah mendorong untuk lahirnya partai-partai politik.

- Demokrasi Rakyat adalah Demokrasi dimana rakyat yang menentukan saat ada masalah penting.

Contoh : Pada saat pemilihan presiden dan wakil presiden

\section{Kesimpulan}

1. Demokrasi adalah gagasan atau pandangan hidup yang mengutamakan persamaan hak dan kewajiban serta perlakuan yang sama bagi semua warga negara.

2. Prinsip demokrasi dibedakan menjadi dua yaitu Prinsip Demokrasi Sebagai Sistem Politik dan Prinsip Non-demokrasi (Kediktatoran).

3. Demokrasi memiliki banyak jenisnya. Yaitu Demokrasi menurut cara aspirasi rakyat (Demokrasi Langsung, Demokrasi Tidak Langsung) dan Demokrasi (Berdasarkan Prinsip Ideologi, Demokrasi Liberal, Demokrasi Rakyat, Demokrasi Pancasila).

\section{Daftar pustaka}

http://sistempemerintahannegaraindonesia.blogspot.co.id/2015/10/pe ngertian-demokrasi-dan-jenis-jenis.html

http://www.informasi-pendidikan.com/2016/02/ciri-ciridemokrasi.html

http://www.tugassekolah.com/2017/09/contoh-contoh-demokrasidalamkehidupan.html

https://guruppkn.com/contoh-perwujudan-demokrasi-di-lingkungan-bangsadannegara 